\title{
Labor Shortages in the Florida Strawberry Industry'
}

\author{
Trina Biswas, Feng Wu, and Zhengfei Guan ${ }^{2}$
}

\section{Introduction}

Florida is the largest supplier of domestic winter strawberries in the United States. In 2016, Florida accounted for approximately $22 \%$ (450 million dollars) of the total US strawberry production value (2,065 million dollars) (USDA-NASS 2017). The total strawberry acreage in Florida reached 10,900 acres in 2016, and the Florida strawberry industry employed an estimated 15,000 workers annually (Guan et al. 2015). However, the industry has faced many challenges over the past few years. Labor shortage is one of the top three challenges.

Labor is the largest cost item in the Florida strawberry production budget; it accounts for about $40 \%$ of production cost. Florida strawberry growers rely mostly on migrant workers for field work. Almost all migrant workers in the United States come from Mexico, and a large portion of migrant workers work without authorization, as indicated by the National Agricultural Workers Survey (USDL 2016). Stricter enforcement of border control and immigration policies is reducing migrant labor supply, while improved economic opportunities are also attracting some workers back to Mexico, further shrinking the pool of migrant workers in the United States. This publication summarizes the results of a labor survey, evaluates labor shortages in the Florida strawberry industry, and discusses potential solutions.

\section{Labor Use Survey}

In cooperation with the Florida Strawberry Growers Association (FSGA), we conducted a labor survey in 2016 to gather information on labor supply and demand during the 2014/15 season and the 2015/16 season. An 18-question inperson interview with strawberry growers was conducted to gather information on grower and farm characteristics, employee recruitment, labor demand and supply, and the perception and use of the $\mathrm{H}-2 \mathrm{~A}$ guest worker program. The growers were asked to provide the following:

- Average number of workers actually needed

- Average number of workers employed

- Average number of workers who quit

- Wage ( $\$ /$ hour, or $\$ /$ flat in piece rate) paid to employees

- Yield abandoned due to labor shortages (flats)

Growers with different operation sizes were interviewed. The total acreage of survey participants was approximately 2,180 acres, or $20 \%$ of the total Florida strawberry acreage.

\section{Labor Demand}

Strawberry production requires intensive labor input. Major tasks include bedding, planting, runner cutting, spraying, and harvesting. In Florida, the demand for farm workers starts in September when bedding begins and

1. This document is FE1041, one of a series of the Food and Resource Economics Department, UF/IFAS Extension. Original publication date July 2018. Visit the EDIS website at http://edis.ifas.ufl.edu.

2. Trina Biswas, research associate; Feng Wu, research assistant scientist; and Zhengfei Guan, assistant professor; Food and Resource Economics Department, UF/IFAS Gulf Coast Research and Education Center, Balm, FL.

The Institute of Food and Agricultural Sciences (IFAS) is an Equal Opportunity Institution authorized to provide research, educational information and other services

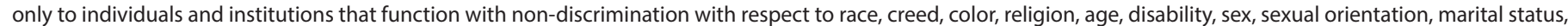

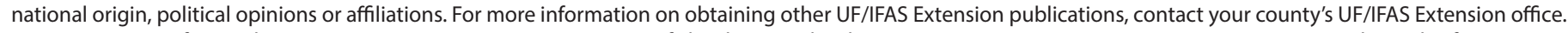
U.S. Department of Agriculture, UF/IFAS Extension Service, University of Florida, IFAS, Florida A \& M University Cooperative Extension Program, and Boards of County Commissioners Cooperating. Nick T. Place, dean for UF/IFAS Extension. 
continues through the following April when strawberry harvesting ends. Workers are needed for planting in October, weeding, spraying, and runner cutting in November, and harvesting from late November through March. The demand for workers fluctuates during the season. It is lowest during the bedding season in September and highest during the peak harvesting season in February and March. On average, growers need 39 workers per 100 acres of land in September. The demand increases to 57 workers per 100 acres in November. Approximately 108 and 112 workers per 100 acres are needed for harvesting in February and March, respectively.

The survey suggested that the average percentage of workers who quit during the peak harvesting season is higher than it is during the rest of the season. Competition from other crops and lower wage rates during the peak harvesting season are among the main reasons that workers quit. According to our survey, on average, workers received $\$ 2.50$ per flat of strawberries in November, while they earned \$1.75 per flat during February and March. Florida strawberry growers also face competition from blueberry growers during the harvesting season. Workers travel north (in or out of state) to harvest blueberries during February and March because the wage rate is better and work is somewhat easier (Charles 2016; Guan, Quishim, and Wu 2018).

\section{Labor Shortages}

Almost $80 \%$ of the respondents reported facing labor shortages during the entire strawberry season. The labor shortage was more serious during the peak harvesting period, especially for large farms. Only $20 \%$ of the respondents who reported hiring workers through the $\mathrm{H}-2 \mathrm{~A}$ program did not have labor shortage issues during the harvesting season. Figure 1 presents the number of workers required and the number actually employed by the strawberry growers. On average, 43 workers were employed at the beginning of the harvesting season in November. The growers required around 57 workers for 100 acres of land, suggesting a shortage of 14 workers. During March, growers needed 112 workers per 100 acres but were only able to hire 77, resulting in a shortage of 35 workers per 100 acres. The graph shows that the labor shortage became more severe through the season (except in January where there was a dip). In March, labor shortages were the most severe because workers migrated to other crops or regions (Guan, Quishim, and Wu 2018).

All respondents reported paying at least the minimum hourly wage rate during the strawberry season. At the

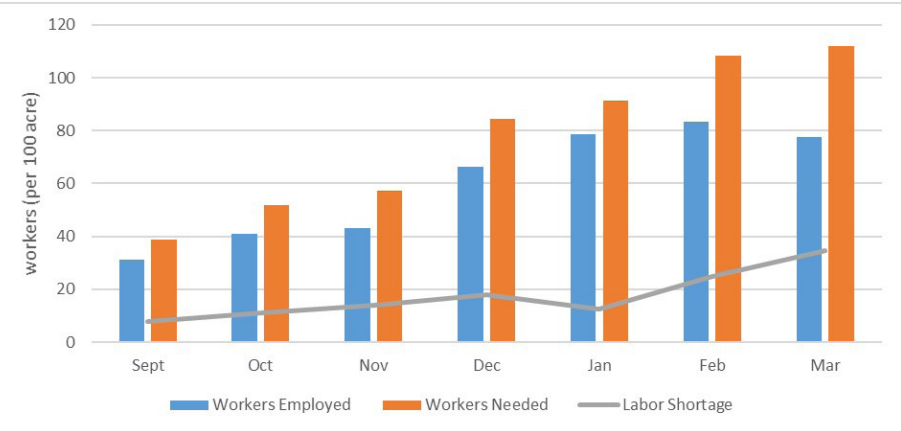

Figure 1. Labor demand, supply, and shortages during the 2014/15 strawberry season.

Credits: Strawberry Industry Labor Survey, UF/IFAS GCREC, 2016

beginning of the season when the yield is low, a high piece rate must be paid to meet the minimum wage requirement. The growers who hired $\mathrm{H}-2 \mathrm{~A}$ workers reported paying more per hour than other growers.

\section{Conclusion}

Labor shortages are a major threat to the Florida strawberry industry. The current labor crisis in Florida is a result of the shrinking pool of migrant workers and the unavailability of American workers. Labor shortage increases the labor cost of strawberry growers and makes it even more difficult to compete with the low-cost Mexican strawberry industry.

To reduce labor shortages, Florida growers are relying on the $\mathrm{H}-2 \mathrm{~A}$ guest worker program to hire foreign guest workers. The respondents in our survey who hired $\mathrm{H}-2 \mathrm{~A}$ workers reported that they did not face any labor shortages during the strawberry season. However, the $\mathrm{H}-2 \mathrm{~A}$ program is expensive because $\mathrm{H}-2 \mathrm{~A}$ workers receive a higher, adverse effect wage rate (AEWR) as well as free housing and transportation. Growers who hire H-2A workers also report that the process is complicated and time-consuming.

Effective use of the $\mathrm{H}-2 \mathrm{~A}$ program may require diversifying the crop mix (Guan et al. 2015). Given that a large labor force is only required during the peak harvesting time, growers can extend the potential contract period for $\mathrm{H}-2 \mathrm{~A}$ workers by diversifying the crop mix. A longer contract period can significantly reduce the hiring and overhead costs per unit of harvested product such as visas, transportation, and housing (Guan et al. 2015). Diversifying crops can also extend the contract period for domestic workers who prefer permanent rather than seasonal employment. An extended contract period will thus encourage domestic workers to stay, which will help alleviate the labor shortage problem.

To address labor shortages, growers are also looking to adopt labor-saving technologies. Growers led by the Wish 
Farms are investing to develop mechanical harvesters. Mechanical harvesting has the potential to significantly reduce production costs, increase industry competitiveness, and induce expansion of the industry. More importantly, it will provide a reliable replacement for labor in the face of a diminishing labor pool.

\section{References}

Charles, D. 2016. "For pickers, blueberries mean easier labor but more upheaval." NPR. Accessed on June 6, 2018. http://www.npr.org/sections/thesalt/2016/07/13/484015376/for-pickers-blueberries-meaneasier-labor-but-more-upheaval

Guan, Z., F. Wu, F. Roka, and A. Whidden. 2015. "Agricultural labor and immigration reform." Choices 30(4): 1-9.

Guan, Z., B. Quishim, and F. Wu. 2018. The Migration Pattern of Florida Seasonal Farmworkers. Gainesville: University of Florida Institute of Food and Agricultural Sciences. In press.

U.S. Department of Agriculture, Economic Research Service (USDA-ERS). 2017. "Farm labor." Accessed on June 20, 2018. https://www.ers.usda.gov/topics/farm-economy/ farm-labor/

U.S. Department of Agriculture, National Agricultural Statistics Service (USDA-NASS). 2017. "Quick stats." Accessed on June 20, 2018. https://quickstats.nass.usda.gov/

U.S. Department of Commerce, U.S. Census Bureau (USDC-USCB). 2016. “USA Trade Online." Accessed on June 20, 2018. https://usatrade.census.gov/

U.S. Department of Labor (USDL), Employment and Training Administration. 2016. "Findings from the National Agricultural Workers Survey (NAWS) 2013-2014.” Accessed on June 20, 2018. https://www.doleta.gov/agworker/pdf/ NAWS_Research_Report_12_Final_508_Compliant.pdf

Wu, F., Z. Guan, and M. Garcia-Nazariega. 2017. Comparison of Labor Costs Between Floridian and Mexican Strawberry Industries. FE1023. Gainesville: University of Florida Institute of Food and Agricultural Sciences. http:// edis.ifas.ufl.edu/fe1023 